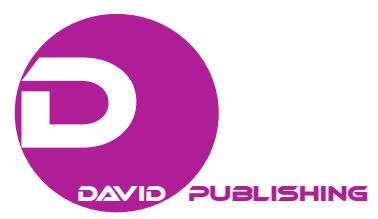

\title{
Citizenship and Migration: The Case of Japan
}

\author{
Yu Jin Woo \\ University of Virginia, Virginia, USA
}

\begin{abstract}
It is conventional wisdom that policy outcomes within consolidated democracies are based on a compromise between preferences of the general public and those of politicians. However, it is questionable whether these divergent incentives are truly translated into migration policy, and if so, how that process occurs. By treating actors' preference formation process as a causal mechanism, this paper hypothesizes the citizenship regime plays a central role in constructing threat perception harbored by the general public while altering politicians' strategic calculations on electorate. Specifically, I argue natives under a jus sanguinis (by ancestry) regime are less welcoming toward migrants, because they are less exposed to an environment where migrants have equivalent social and political rights, fulfilling their duties as full members of the host country. Thus, natives do not re-categorize these initial outsiders as in-group members. Meanwhile, politicians in a jus sanguinis regime have less incentive to enact generous policies toward migrants, because they are excluded from the voting group. In sum, countries adopting this citizenship principle are likely to be less willing to incorporate migrants. This paper uses Japan as a case to trace how this causal mechanism has operated in a country under a strict jus sanguinis principle.
\end{abstract}

Keywords: migration policy, citizenship law, Japan

\section{Introduction}

Japan is commonly regarded as a country that is closed against migrants. It does not allow their entries in a large size, granting restricted rights. As an attempt to understand this tendency, this paper claims that countries' respective citizenship law, which is normally classified into jus soli (by birthplace) and jus sanguinis (by ancestry), is a fundamental cause. Simply put, countries under jus sanguinis principle are more likely to impose a restrictive migration policy, because (1) the general public tends to reveal a greater prejudice and fear against migrants (societal nature); and (2) migrant groups are excluded from electorate, and thus, they would not contribute to votes (electoral nature). Japanese migration policy, under a long Liberal Democratic Party's ruling during postwar era, is relatively deterring due to its strict citizenship law based on blood. In order to demonstrate this mechanism, I trace Japanese public attitude and political calculations, which have governed its migration policy until today.

\section{Theoretical Framework}

Acquisition of a country's citizenship means a full membership to the community with a guarantee of civil, political and social rights (Marshall, 1950, p. 6). Because citizenship law is the basic component in identifying in which society individuals belong to, it naturally influences how natives view migrants. According to Allport (1954), intergroup contact will lead to a favorable attitude toward initial out-group members due to decreasing 
prejudice and increasing familiarity. In other words, frequent and consistent interaction between natives and migrants would reduce anti-migration sentiment, and natives would re-categorize them into in-group members. He claims however that this does only occur when those initial out-group members acquire equal status and rights. The largest distinction between jus soli and jus sanguinis regimes is that natives in the former regime recognize that migrants can obtain the same status as theirs, and they are exposed to such a situation. On the contrary, natives under the other rule are not used to this situation, and thus, their conception on citizenship continues to be strongly based on ancestry. They may feel closer to migrants as a stock of foreign population grows. However, they would not feel motivated to share the same rights with migrants. In sum, natives, who do not have an exposure to migrants with equal rights (in this case, jus sanguinis), will feel a greater fear toward migrants (H1 on societal nature).

In jus sanguinis regime, this negative public attitude on migrants is likely to discourage politicians from enacting open migration policies due to a fear that they may lose votes from the general public. Adding to this hurdle, politicians grant more rights for migrants as a rational mean to survive contestation via winning new votes from them (Brubaker, 1992; Howard, 2009; Janoski, 2010; Joppke, 1999; Renshon, 2001). In other words, whether migrants are capable of obtaining a political right becomes another matter of interest. Of course, there are two other methods for migrants to obtain political rights - a possibility of noncitizen franchise and an option of naturalization (jus domicilis principle). Although there is a variation across countries, there is a common tendency that jus soli countries apply these methods much more frequently (Bauböck, 2005; Earnest, 2008, 2015, OECD report, 2011). Therefore, it is safe to rely on this dichotomous distinction of citizenship law; Political parties in jus sanguinis regime take interests of migrants less seriously, because their votes do not count (H2 on electoral nature).

\section{Japanese Citizenship Law and Migration Policy}

Japanese nationality is granted based on jus sanguinis since 1952. Because of this strict principle by ancestry, foreign nationals experience a great difficulty in acquiring Japanese nationality for themselves. Those permanent residents (Eijusha) are largely classified into two categories: regular (Ippan-Eijusha) and special (Tokubetsu-Eijusha). The latter encompasses ethnic Koreans and Chinese, who stayed in Japan after the end of the WWII. This status passes onto their descendants, implying that the children of immigrants cannot automatically become citizens by birth. Although permanent migrants can become Japanese citizens via naturalization (kika), six requirements set by the Naturalization Law (No. 147 of 1950 originally; No. 88 of 2008 as the most recently amended as of 2015; Article (5) are frequently criticized to be enormously austere. Consequently, many permanent migrants tend to be dispirited prior to submitting applications. The average naturalization rate in past 10 years has been less than three percent. One of main obstacles, for instance, is the documents; asking whether the other family members are willing to naturalize or support the applicant's decision, and whether neighbors or colleagues know the applicants' original nationality. Since most of special permanent residents use Japanese names, they become reluctant to let their surroundings to discover their original descent, and thus, give up on naturalization (Lee, 2005, pp. 46-47).

At present, besides the two types of permanent migrant status, there are another 25 visa types to distinguish temporary migrants. Since the First Fundamental Plan on Employment Measures adopted in 1967, the government outspokenly announced to attract migrants, who possess high and special skills or knowledge, while discouraging inflow of low skilled labor migrants. However, there have been frequent cases where this 
policy goal was disrupted. For instance, middle- and small-sized firms begun to employ irregular migrants to minimize the cost. To counteract against this trend, Japan initiated invitation of returning Japanese descents (Nikkeijin) while importing necessary labor from neighboring countries, such as China, Korea and Philippines. What is noticeable from this policy revision is that instead of coping with culturally, religiously and ethnically different foreign aliens, it sought to rely on those, who possessed the same ancestry or similar values and norms (Toida, 2005, p. 16). In addition, labor supply by foreign students also dramatically amplified (Nokawa, 2012, p. 200). The eventual result was that most of migrants continued to be low-skilled or irregular, despite Japan's intention to attract high-skilled ones. Debates on these issues became heated again since the early 2000s. Subsequent moderations on migration policies $(2004,2005,2007)$ kept highlighting their goals to only admit qualified migrants, although there was no major shift.

The most noticeable moderation of migration policy since the millennium is perhaps the implementation of point-based system in 2012. Unlike Canadian or Australian point systems, Japanese one does not guarantee a direct or automatic road to a permanent settlement in the very early stage. In other words, this system stands parallel with existing immigration law, which requires a job offer prior to entry. Because of these difficulties in acquiring Japanese nationality, a cleavage between Japanese nationals and migrants is stark. Consequently, Japanese migration policy seems to be more dedicated on temporary migrants, and hence, it approaches migrants from an economic standpoint. The next section elaborates how the citizenship law has shaped natives' perception on migrants that eventually filters into migration policymaking.

\section{Japanese Public Perception on Migrants}

In order to examine Japanese public attitude toward migrants, I compare multiple surveys. I first scrutinize general perception toward migrants among Japanese natives. To do so, I mainly rely on "National Identity II" survey results composed by International Social Survey Program (ISSP, 2003) to generate a cross-country comparison (see Figure 1) ${ }^{1}$. In regards to the first statement (Question 1), 70\% of Japanese respondents agreed that immigrants increase crime rates while only $48.5 \%$ of total respondents across countries did. The similar outcome is also noticeable in other survey data, such as "opinion poll on public order" collected by the Cabinet Office, Government of Japan (2004, 2006, 2012). It seems that a great portion of Japanese citizens believes their public order has been exacerbating $[86.6 \%(\mathrm{~N}=1,961)$ in $2004,84.3 \%(\mathrm{~N}=1,795)$ in 2006 , and $81.1 \%(\mathrm{~N}$ $=1,956)]$, while they mainly blame on migrants as its cause.

The second group of questionnaires (Questions 2 and 3) asks on economic dimension of migrants. The data shows that Japanese people relatively do not consider migrants as an economic threat. Noro's (2002) survey asks similar questions in regards to temporary foreign workers $(\mathrm{N}=564)$. His outcomes reveal a stronger negative image on economic migrants. Thus, the overall results are mixed, and this difference probably emerges due to wordings of questionnaires. On the other, Japanese natives tend to be more generous toward migrants from human rights standpoint while they do not embrace disruption of their cultural solidarity or personal lifestyle. ISSP outcome shows that Japanese natives are highly skeptical about migrants' contribution

\footnotetext{
1 National Identity Survey II (2003) by ISSP includes Australia, Austria, Bolivia, Bulgaria, Canada, Chile, Czech Republic, Denmark, Finland, France, Germany, Great Britain, Hungary, Ireland, Israel, Japan, Latvia, Netherlands, New Zealand, Norway, Philippines, Poland, Portugal, Republic of Korea, Russia, Slovakia, Slovenia, South Africa, Spain, Sweden, Switzerland, Taiwan, United States, Uruguay, and Venezuela. I acknowledge that some countries in the dataset are not democracies while my hypothesis is bounded to democratic countries. Because I use this data in order to parse out public's view on citizenship and migrants, I decided to include all participated countries.
} 
to cultural diversity (Question 4) while they still value minorities' culture and custom (Question 5) as well as rights of foreign children and legal migrants (Questions 6 and 7). The similar results also emerge from Noro's data on temporary migrants. More importantly, even the altruistic attitude evaporates when the questionnaires involve specific conditions or situations that can directly influence respondents' environments. For instance, according to opinion survey, conducted by Cabinet Office, on human rights (2007), 59.3\% claimed that foreigners' human rights needed to be preserved regardless of their nationality, although $57.1 \%$ stated it is inevitable that foreigners experience unreasonable treatment, because they do not understand Japanese values or cultures. In addition, a survey conducted in Japan and Sweden by Otsuka et al. (2011) finds that Japanese respondents are much more pessimistic about migrants.

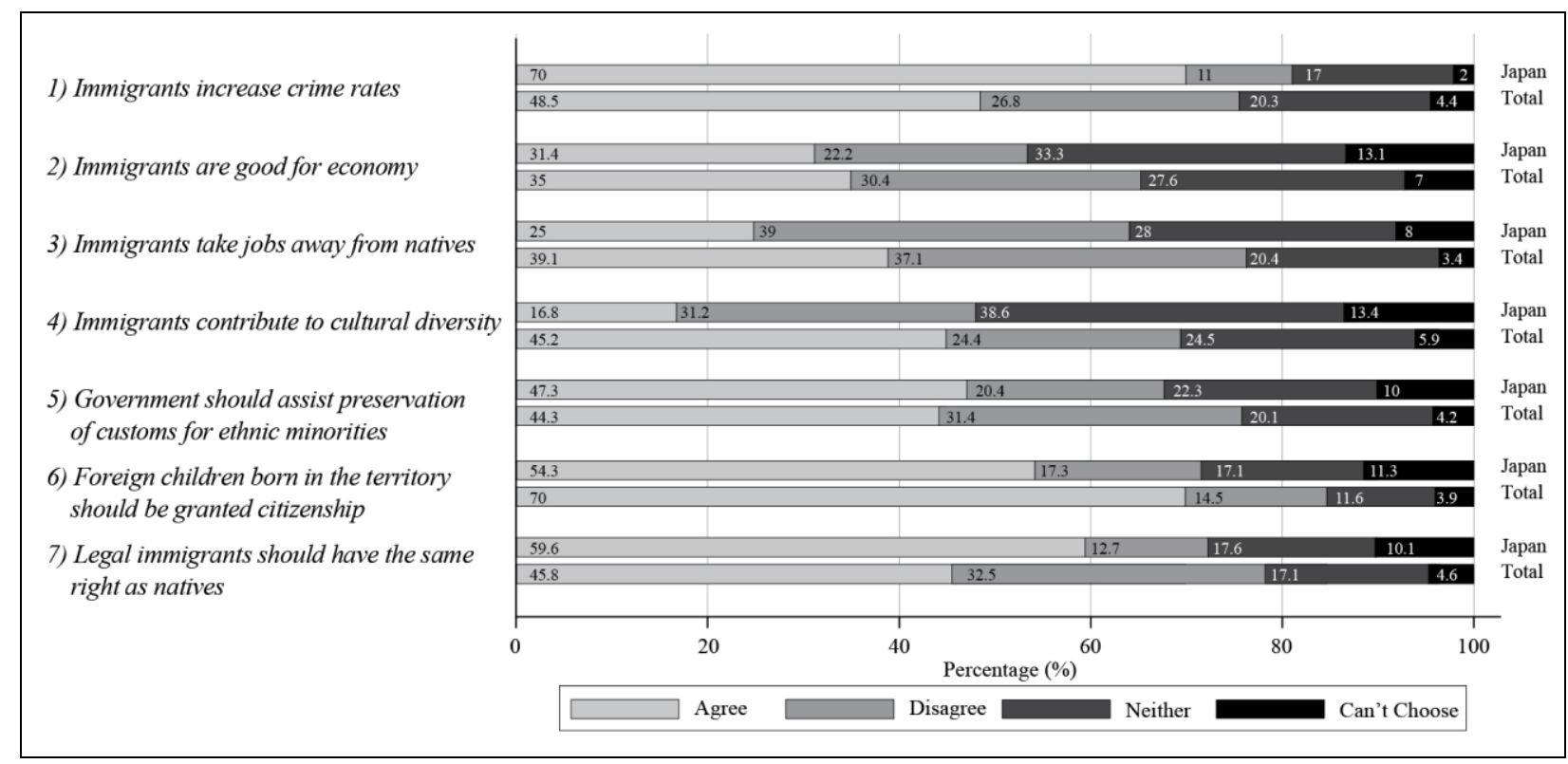

Source: IPPS, 2003.

Figure 1. Public attitude toward migrants.

Overall, there is a recurring tendency on Japanese attitude on migrants. Although they value general human rights, they tend to associate "overall migrants" with a negative image while they are sensitive about preservation of cultural solidarity. The reasons behind can be traced down to their historical socialization with "others". Kim's (2010) survey indicates that majority of Japanese citizens (63\%) claimed they did not have any close foreign acquaintance $(\mathrm{N}=106)$. This indicates that Japanese natives tend to have a negative attitude against migrants even without direct or personal contacts with them. To put it another way, there is a great plausibility that their perception on migrants is a product of prejudice, which is based on social norms and values, instead of actual encounter. The less frequent contact with foreigners seems to induce low-level interests as well as negative stereotypes toward migrants, and thus, the cleavage between natives and foreigners has been growing.

The question then carries onto why Japanese citizens have this prejudice against migrants. In fact, Japanese postwar discrimination against "foreigners" originates from a divide between Japanese natives and special permanent migrants. Until today, this cleavage has led frequent social conflicts (i.e., Hate Speech), and these events in turn exacerbated negative images on each other. As a result, this segregation between natives and special permanent migrants has spread to overall image of migrants, inducing outcomes shown in various 
opinions surveys.

Subsequently, there is a necessity to closely examine why this category initially emerged. Most of Zainichi at recent years are born and raised in Japan. However, because they do not share Japanese ancestry, they are strictly excluded from many rights. If Japan were a mixed regime where jus soli principle was implemented or naturalization procedure was easier, the number of Zainichi, who succeeded in obtaining Japanese citizenship, would have been larger. As a consequence, the fundamental racism in Japan would have been ameliorated, and the society would have transformed into more culturally diversified environment. Under such a circumstance, the public survey outcomes may have been different. Because Japanese citizenship law is strictly based on blood, those natives are used to a situation where migrants do not enjoy the same rights as theirs. Thus, they are hesitant to grant greater rights to migrants. Specifically, they regard that it is natural to allow controlled rights to temporary migrants while they feel threatened to give greater rights (in this case, political) to permanent migrants.

\section{Political Calculation on Migrants}

The previous section has elaborated an effect of citizenship law on Japanese public perception toward migrants. On this matter, the two main political parties in recent era, Liberal Democratic Party (LDP; Jiminto) and Democratic Party of Japan (DPJ; Minshuto), reveal different approaches. The former holds a more restrictive and conservative attitude, while the latter prefers more open and incorporating policies. DPJ members, such as Chiba and Hosokawa argued Japan needed to adopt amnesty for irregular migrants, and to find a way to integrate them into Japanese society instead of simply expelling or assimilating them. On the contrary, LDP has sustained its opposing attitude, claiming that it would only increase a number of the irregular (171st National Assembly Legal Committee No. 4 , March 24, 2009; No. 10, May 12, 2009). Furthermore, the recent debate on granting regional voting rights to permanent residents during DPJ rule (2009-2012) highlights these contrasting standpoints. Both DPJ and Komeito have expressed a positive attitude toward the idea. However, LDP has repeatedly argued that the permanent migrants needed to naturalize in order to obtain the right, because voting right is a fundamental right of Japanese citizens (although some of LDP members also called for granting political rights). Eventually, LDP's overall opposition led to a failure of the proposal.

To understand causes to the firmly opposing attitude of LDP, I evaluate interest groups that support the party. Many scholars note that LDP has succeeded in sustaining its position as a dominant party for such a long period of time, because its main emphasis has been on attracting votes from various interest groups as an exchange of policies (Yamashita, 2009). The two most powerful rent-seeking groups have been Agricultural Cooperative (Nokyo) and Employers' Association (Keidanren) (2003). Since the beginning of postwar era, agricultural cooperative has been a strong advocate, and thus, LDP has continued protectionist policies for domestic agricultural profits (Davis, 2003; Yamashita, 2009). Considering the fact that the Central Union of Agricultural Cooperatives (JA-Zenchu) involves 9,690,000 union members by the year of 2010, it is apparent that this interest group has long provided a stable voting basis for LDP. On the other, Employers' Association (2004) has been widely known for its financial lobby to LDP in order to support the latter's capitalist approach. Thus, there is a wide recognition that it pays to LDP to buy policies (Nikkei Newspaper, 2014).

The influence by the two dominant interest groups is perceptible in migration policymaking. Although LDP has enacted rather restrictive policies against migrants' rights or integration, it has allowed both high- and low-skilled migrants under a temporary scheme. The intention is quite apparent; LDP has attempted to satiate 
labor shortage in agricultural sector while Keidanren has continuously pushed for attracting greater number of skilled migrants. For instance, since 2000, Keitandren kept insisting for greater attraction of migrants with professional knowledge (Towards a Lively and Attractive Japan, 2003; Recommendation on Problems Arising from Incoming Migrants, 2004). As a result, the most recent change in migration policy took place by adopting point-based system. In fact, it was originally LDP, which suggested introduction of this system prior to losing its power in 2009. When the party first proposed the idea, it never intended to enlarge the stock of overall migrants. According to a report, "Conference on Advanced Human Resources Promotion: For a Full-Scale Process on Recruiting High Skilled Foreigners (2009)", it rejects a point system that is used in other countries, which allow an entry of migrants without a job offer as long as they satisfy pass marks. Instead, it insists a demand-driven mechanism that only allows migrants' entries for demanded labor market. A moderation of the system (2015) continues to reveal LDP's emphasis on temporariness of migrants and domestic economic needs.

Despite the historical tie between LDP and its rent-seeking groups, this relationship was once hampered due to fears arising from former Prime Minister Koizumi's strong insist on privatization of postal service. Oshiro et al. (2010) noted that votes from agricultural sector for LDP was extremely high for the 43th general election; however, its effect disappeared by the 45th election (p. 18). As a result, these votes temporarily leaked to DPJ. In addition to its appeal to attract votes from the general public, the votes from agricultural sector assisted DPJ becoming a major party during this election. The implication is that DPJ's basis for votes is quite fragile, and therefore, it needed to generate a consolidated and stable winning coalition. When one scrutinizes an interest group that has not benefitted from policies by LDP, the migrant group quickly emerges as one of few plausible candidates. In reality, the former Prime Minister Noda made an appearance to a festival held at Chiba prefecture by the Korean Residents Union (Mindan) in 2009. He made a speech, in which he stated that he could win the election because of the support from the union. In a budget meeting of House of Councilors in 2011, he eventually admitted that he previously received briberies from two officials of the union (Ministry of Justice, 2015). The speculation here is that there has been a tie between DPJ and Mindan, and the latter intended to financially maneuver DPJ's policymaking.

One then needs to scrutinize why DPJ decided to co-opt migrants, instead of other domestic groups, when there was likelihood that favorable migration policy may disrupt existing public support. In fact, when domestic conditions along with party image of DPJ are taken into account, incorporating permanent migrants by granting regional voting rights turns out to be a highly rational strategy. First, voting rate in Japan has been declining. According to the Association for Promoting Fair Elections (Akarui Senkyo Suishin Kyokai), none of major elections has recorded a voting rate higher than $70 \%$ since 1993. Moreover, a continuous public surveys by Kono et al. (2009) between 1973 and 2008 ( $N=5,400$ per year) indicate that a rate of swing voters without any party affiliation has exceeded 50\% since 1998 (p. 6). These outcomes suggest that it would be wiser to formulate firm supporting groups in order to steadily maintain political power, instead of solely relying on swing voters, who irregularly go to elections.

Second, granting voting rights for permanent migrants fits with DPJ's image as a center-left party, which advocates preservation of fundamental human rights. As shown in the previous public polls, Japanese citizens seem to be sympathetic when it comes to human rights matter. Additionally, although there was a heated public debate on this issue, many public polls seem to indicate that Japanese natives are generally more optimistic about attributing regional voting rights to permanent residents as long as it is the only right permitted for them and it will not be misused by temporary migrants (Kim, 2010; Maruyama et al., 2006; Matsutani et al., 2005). 
By observing the public attitude, DPJ may have assumed the public opinion would not to be problematic. Considering these conditions, DPJ's choice on co-opting permanent migrants by limiting its policy proposal to regional voting rights was the most strategic approach to stay in office.

When the indispensable cause to this situation and choices made by DPJ is taken into account, it is impossible to neglect Japanese jus sanguinis principle. Besides fears that the general public might hold against migrants, the benefit by incorporating migrant groups is usually minimal under this citizenship law. This explains why Japanese long-term ruling party, LDP, has treated them from an economic framework by emphasizing temporariness and domestically demanded types of labor. As a consequence, Mindan had to lobby DPJ, and this relatively innate party ended up pushing for political rights of permanent migrants to consolidate its political position. If Japanese nationality were provided by birthplace, LDP would have enacted more encompassing integration policies alongside economic concerns. Subsequently, this may have led ethnic minorities' groups into its winning coalition. Nevertheless, it is evident that Japanese citizenship law has a trajectory on contemporary migration policy outcome.

\section{Conclusion}

Although many researchers treat Japan as a hostile country against migrants, it is no doubt that Japan admits a lot of foreigners. A more articulate description would be that Japan would welcome migrants, but their permitted duration of stay or granted rights will be very limited. I have argued that a vital root to this tendency lays in the nature of citizenship law - in this case, a principle by ancestry. Because people in Japan are not used to face culturally or ethnically dissimilar aliens, who possess full membership, they naturally feel more fearful. Meanwhile, politicians rationally calculate a way to maximize their stay in office. Hence, when they treat migration policies, they consider the public sentiment on migrants as well as how many new votes they can gain by becoming generous toward migrants. In this sense, there is no incentive for politicians in Japan to enact such a policy, and this explains why LDP has long treated migrants merely as foreign economic contributors.

\section{References}

Allport, G. W. (1954). The nature of prejudice. Cambridge: Addison-Wesley Publishing Company.

Akarui Senkyo Suishin Kyokai [Association for Promoting Fair Elections]. (n.d.). Retrieved May 10, 2015, from http://www.akaruisenkyo.or.jp/070various/

Bauböck, R. (2005). Expansive citizenship: Voting beyond territory and membership. Political Science and Politics, 38(4), 683-687.

Brubaker, R. (1992). Citizenship and nationhood in France and Germany. Cambridge: Harvard University.

Cabinet Office, Government of Japan. Yoronchosa [Opinion Survey]. (2015). Retrieved May 15, 2015, from http://survey.gov-online.go.jp

Davis, C. L. (2003). Food fights over free trade. Princeton: Princeton University.

171st National Assembly Legal Committee. (No. 4 on March 24, 2009 and No. 10 on May 12, 2009). Diet Proceedings. Retrieved May 10, 2015, from http://kokkai.ndl.go.jp/cgi-bin/KENSAKU/swk_srch.cgi?SESSION=42587\&MODE=1

Earnest, D. C. (2008). Old nations, new voters: Nationalism, transnationalism and democracy in the era of global migration. Albany: State University of New York Press.

Earnest, D. C. (2015). Explaining the electorate: Comparing the noncitizen voting practices of 25 democracies. International Migration and Integration, 16, 1-25.

Howard, M. M. (2009). The politics of citizenship in Europe. New York: Cambridge University Press.

ISSP Research Group. (2003). International Social Survey Programme: National Identity II-ISSP. GESIS Data Archive, Cologne. ZA3910 Data file Version 2.1.0. 2012. Retrieved May 15, 2015, from https://dbk.gesis.org/dbksearch/sdesc2.asp?no=3910

Janoski, T. (2010). The ironies of citizenship. New York: Cambridge University Press. 
Joppke, C. (1999). Immigration and the nation-state: United States, Germany, and Great Britain. Oxford: Oxford University. Keidanrenga Saikai: Kigyono Seiji Kenkin, Nanno Tame? [Keidanren Resumes: Political Contributions by Companies, What is that for?]. (September 27, 2014). Nihon Keizai Newspaper. Retrieved May 16, 2015, from http://www.nikkei.com/article/DGXDZO77562440W4A920C1W07001/

Kim, A. K. (2010). Gaikokujin Chiho Sanseiken Fuyani Kansuru NihonjinnoIshiki Chosa [An opinion survey among Japanese local people on granting local election rights toward foreign residents]. Journal of Social Science, Nagoya University, 47(2), 43-51.

Kodojinzai Ukeire Suishin Kaigi (The Conference on Advanced Human Resources Promotion). (2009). Gaikoku Kodojinzai Ukeire Taisaku no Honkakuteki Tenkaiwo [Conference on Advanced Human Resources Promotion: For a Full-Scale Process on Recruiting High Skilled Foreigners]. Retrieved April 30, 2015, from http://www.kantei.go.jp/jp/singi/jinzai/dai2/houkoku.pdf

Komai, H. (1993). Gaikokujin Rodosha Teichakueno Michi [A way for foreign laborers'settlement]. Tokyo: Akashi Shoten.

Kono, K., Takahashi, K., \& Hara, M. (2009). Nihonjinno Ishiki Henkano 35nenno Kiseki [Trajectory of altering Japanese consciousness over 35 years]. Hosokenkyuto Chosa [Broadcast Research and Survey]: pp. 2-23.

Lee, S. (2005). Naturalization policy in Japan. Ryukoku University Institutional Repository Departmental Bulletin Paper 36, pp. 40-50.

Marshall, T. H. (1950). Citizenship and social class. London: Pluto Perspective.

Maruyama, M., Ryosuke, T., Hiroshi, M., Shigeru, K., Naoto, H., Takuya, Y., \& Mitsuru, M. (2006). Darega 'Kakumeiha Chiji'wo Shijisurunoka: Hashimoto Daijiro Kochiken Chijiheno Tohyokodowo Chushinni [Who supports reformist governors?: Analyzing the voting behavior in Kochi prefecture]. Social Science Research, University of Tokushima, 19, 187-229.

Matsutani, M., Ryosuke, T., Masao, M., Hiroshi, M., \& Naoto, H. (2005). Ukeireto Togowo Meguru Shakaiishiki [Social consciousness on acceptance and integration]. Asia Pacific Review, pp. 2-14.

Nihon Keizai DantaiRengokai [Employers' Association]. (2003). Katsuryoku to Miryoku Afureru Nihon wo Mezashite [Japan Employers Association. Towards a lively and attractive Japan]. Retrieved April 15, 2015, from https://www.keidanren.or.jp/japanese/policy/vision2025.html

Nihon Keizai DantaiRengokai [Employers' Association]. (2004). Gaikokujin Ukeire Mondaini Kansuru Teigen [Recommendation on problems arising from incoming migrants]. Retrieved April 15, 2015, from http://www.keidanren.or.jp/japanese/policy/2004/029/

Nokawa, S. (2012). Rodohogenrino Saikosei [Reconstruction of labor law principles]. Tokyo: Seibundoh.

Noro, N. (2002). Gaikokujin Rodoshato Iminno Ukeire [Acceptance of foreign workers and immigrants]. LDI Report, 135, 2 4-25. OECD. (2011). International migration outlook 2011. Paris: OECD Publishing.

Oshiro, K., Yu, S., Risa, M., \& Toshihiko, M. (2010). Seiken Kotainiyoru Henkano Kenshoto Teigen [Verification of changes due to regime shift and further recommendations]. Presented paper at Inter-University Seminar for the Future of Japan (ISFJ) Policy Forum.

Otsuka, M., Akiyama, M., Mori, K., \& Hoshino, H. (2011). Kachikan, Rodokan, Raifu Stairu Nadoni Kansuru Nihonto Hokuono Kikakuchosakenkyu Dai lji Hokoku [Comparative study of values, work ethics, and lifestyle in Japan and Sweden: An initial report]. Human Science Research, Bunkyo University Faculty of Human Sciences, 33, 105-119.

Renshon, S. A. (2001). Dual citizenship and American national identity. Washington: Center for Immigration Studies.

The Ministry of Justice. The Nationality Law Section. (2015). Retrieved May 15, 2015, from http://www.moj.go.jp/ENGLISH/information/tnl-01.html

Toida, K. (2005). Nihonno Uchinaru Kokusaika-Nikkei Nu-Kama-to Watashitashi [Japanese internal globalization-Nikkei new comers and us]. Tokyo: KokonShoin.

Yamashita, K. (2009). NokyonoOotsumi: "Nosei Toraianguru”ga Maneku Nihonno Shokuryo Fuan [A mortal sin of agricultural cooperative: Japanese food insecurity caused by agricultural policy triangle]. Tokyo: Takarajimasha.

Zennoh [National Federation of Agricultural Cooperative Associations]. (2015). Retrieved May 10, 2015, from http://www.zennoh.or.jp/about/english/index.html 